\title{
A dangerous adverse event in the use of dabigatran
}

\author{
Manuel Monti, ${ }^{1}$ Giovanni Maria Vincentelli, ${ }^{2}$ Francesco Borgognoni, ${ }^{1}$ Giuseppe Murdolo, ${ }^{1}$ Feliciano Menghini ${ }^{1}$ \\ ${ }^{1}$ Emergency Department, AUSL UMBRIA1, Assisi (PG); ${ }^{2}$ Emergency Department, Fatebenefratelli Hospital, Roma, Italy
}

\section{Letter to the Editor}

In recent years, the new oral anticoagulants, direct inhibitors of the $\mathrm{X}$ factor (rivaroxaban, apixaban) or of the thrombin (dabigatran), have consolidated their role in the prevention of venous thromboembolism (in case of total hip replacement) as well as in the cardioembolic stroke prophylaxis (in patients with nonvalvular atrial fibrillation). Moreover, more recently, rivaroxaban and apixaban are indicated in the treatment and prevention of recurrent deep vein thrombosis and pulmonary embolism. ${ }^{1}$

The most serious side effect is the gastro intestinal bleeding that, however, can be often avoided by a careful assessment of the individual patient. ${ }^{2}$

Here, we draw attention to an extremely rare side effect, perhaps one of the first cases described in the literature, occurred in a patient with non-valvular atrial fibrillation treated with dabigatran 110 bid for thrombo embolic prophylaxis.

We describe the case of a patient, male, 88 years old, transported to the Emergency Department of the Assisi Hospital with intense dyspnea associated with tirage and cornage. These clinical symptoms arose two minutes after taking one capsule of $110 \mathrm{mg}$ dabigatran that the patient accidentally smashed in the mouth.

Blood tests were performed [white blood cell

Correspondence: Manuel Monti, AUSL UMBRIA1 U.O. PS/118, via V. Muller 1, 06081 Assisi (PG), Italy.

E-mail: montimanuel@tiscali.it

Key words: Dabigatran; edema of the vocal cords; frail patients.

Received for publication: 29 July 2015.

Revision received: 24 September 2015.

Accepted for publication: 5 November 2015.

This work is licensed under a Creative Commons Attribution NonCommercial 4.0 License (CC BY-NC 4.0).

CCopyright M. Monti et al., 2016

Licensee PAGEPress, Italy

Italian Journal of Medicine 2016; 10:250-251

doi:10.4081/itjm.2015.629
(WBC) 10,830/mmc, neutrophils 74.8\%, lymphocytes $18.8 \%$, monocytes $5.6 \%$, eosinophils $0.6 \%$, basophils $0.2 \%$ C-reactive protein $0.19 \mathrm{mg} / \mathrm{dL}$, electrolytes normal] and a chest X-ray resulted normal. Laboratory findings showed that WBC count and C-reactive protein were slightly increased (Table 1). He had a medical history of hypertension (furosemide $25 \mathrm{mg}$ twice daily and olmesartan $20 \mathrm{mg}$ once daily) for 10 year and diabetes mellitus treated with oral hypoglycemic agents for 7 years. The patient had permanent atrial

Table 1. Blood tests.

\begin{tabular}{lccc}
\hline White blood cell & 10,830 & $\mathrm{mmc}$ & $4.50-10.80$ \\
\hline Red blood cell & 5.39 & & $4.60-6.20$ \\
\hline Hemoglobin & 16.7 & & $13.50-18.00$ \\
\hline Hematocrit & 45.4 & & $40.0-50.0$ \\
\hline MCV & 84.2 & & $80.0-94.0$ \\
\hline MCH & 31 & & $27.0-33.0$ \\
\hline MCHC & 36.8 & & $33.0-37.0$ \\
\hline RDW & 12.2 & & $11.5-16.0$ \\
\hline Neutrophils \% & 74.8 & & $40.0-75.2$ \\
\hline Lymphocytes \% & 18.8 & & $20.5-51.1$ \\
\hline Monocytes \% & 5.6 & & $0.0-13.0$ \\
\hline Eosinophils \% & 0.6 & & $0.5-6.0$ \\
\hline Basophils \% & 0.2 & & $0.15-2.0$ \\
\hline Platelet & 152 & & $130-400$ \\
\hline Glucose & 106 & $\mathrm{mg} / \mathrm{dL}$ & $60-110$ \\
\hline Creatinine & 0.9 & $\mathrm{mg} / \mathrm{dL}$ & $0.70-1.20$ \\
\hline Blood urea nitrogen & 37 & $\mathrm{mg} / \mathrm{dL}$ & $12.5-50.0$ \\
\hline Sodium & 140 & $\mathrm{mmol} / \mathrm{L}$ & $136-145$ \\
\hline Potassium & 3.5 & $\mathrm{mmol} / \mathrm{L}$ & $3.5-5.1$ \\
\hline Calcium & 9.4 & $\mathrm{mg} / \mathrm{dL}$ & $8.6-10.2$ \\
\hline Aspartate transaminase & 25 & $\mathrm{U} / \mathrm{L}$ & $0-40$ \\
\hline Alanine transaminase & 16 & $\mathrm{U} / \mathrm{L}$ & $0-41$ \\
\hline Creatine kinase & 205 & $\mathrm{U} / \mathrm{L}$ & $0-190$ \\
\hline C-reactive protein & 0.19 & $\mathrm{mg} / \mathrm{dL}$ & $0.5-1.0$ \\
\hline & & & \\
\hline MV & & \\
\hline
\end{tabular}

$\mathrm{MCV}$, mean corpuscular volume; $\mathrm{MCH}$, mean corpuscular hemoglobin; $\mathrm{MCHC}$, mean corpuscular hemoglobin concentration; RDW, red cell distribution width. 
fibrillation and, for about two months, had started therapy with dabigatran (90 $\mathrm{mg}$ twice daily).

After an unsuccessfully initial treatment with steroids (hydrocortisone $1000 \mathrm{mg}$ endovenously and aerosols beclomethasone) and $\beta$-adrenergic aerosol, the patient was treated with epinephrine $(1 \mathrm{mg} 1 \mathrm{fL}$ for aerosol) resulting in clinical improvements while persisting a light dyspnea for some hours.

After the adrenaline treatment, the patient was subjected to laryngoscopy that allowed revealing an edema of the vestibule palatine and extensive edema of the vocal cords with a consequent reduction of the airspace.

The clinical scenario described above is the result of an allergic reaction to one or more component of the structure of the drug capsule. In the next months, the patient will be submitted to allergy tests in order to point out the allergen responsible of this severe reaction.

Finally, we found appropriate, especially in patients who have difficulty swallowing, to have the greatest attention to the correct method of taking the drug.

\section{References}

1. Larsen TB, Rasmussen LH, Skjøth F, et al. Efficacy and safety of dabigatran etexilate and warfarin in "real-world" patients with atrial fibrillation: a prospective nationwide cohort study. J Am Coll Cardiol 2013;61:2264-73.

2. Bauersachs RM. Managing venous thromboembolism with novel oral anticoagulants in the elderly and other high-risk patient groups. Eur J Intern Med 2014;25:600-6. 